Negotiating Gendered Identities at Work 
Other books by the authors

GENDER, POWER AND ORGANISATIONS

Susan Halford and Pauline Leonard

GENDER, CAREERS AND ORGANISATIONS

Susan Halford, Mike Savage and Ann Witz 


\section{Negotiating Gendered Identities at Work}

Place, Space and Time

Susan Halford and Pauline Leonard

University of Southampton 


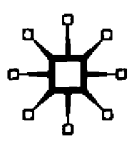

(9) Susan Halford and Pauline Leonard 2006

Softcover reprint of the hardcover 1st edition 2006 978-1-4039-4112-1

All rights reserved. No reproduction, copy or transmission of this publication may be made without written permission.

No paragraph of this publication may be reproduced, copied or transmitted save with written permission or in accordance with the provisions of the Copyright, Designs and Patents Act 1988, or under the terms of any licence permitting limited copying issued by the Copyright Licensing Agency, 90 Tottenham Court Road, London W1T 4LP.

Any person who does any unauthorized act in relation to this publication may be liable to criminal prosecution and civil claims for damages.

The authors have asserted their rights to be identified as the authors of this work in accordance with the Copyright, Designs and

Patents Act 1988.

First published 2006 by

PALGRAVE MACMILLAN

Houndmills, Basingstoke, Hampshire RG21 6XS and

175 Fifth Avenue, New York, N.Y. 10010

Companies and representatives throughout the world

PALGRAVE MACMILLAN is the global academic imprint of the Palgrave Macmillan division of St. Martin's Press, LLC and of Palgrave Macmillan Ltd. Macmillan is a registered trademark in the United States, United Kingdom and other countries. Palgrave is a registered trademark in the European Union and other countries.

ISBN 978-1-349-52046-6

ISBN 978-0-230-50271-0 (eBook)

DOI $10.1057 / 9780230502710$

This book is printed on paper suitable for recycling and made from fully managed and sustained forest sources.

A catalogue record for this book is available from the British Library.

Library of Congress Cataloging-in-Publication Data

Halford, Susan.

Negotiating gendered identities at work : place, space, and time / Susan Halford and Pauline Leonard.

p. cm.

Based on an empizical study of identity making by doctors and nurses working in British National Health Service hospitals.

Includes bibliographical references and index.

1. Sex role in the work environment-Case studies. 2 . Gender identity-Case studies. 3. Spatial behavior-Case studies. 4. Time-Social aspects-Case studies. 5. Identity (Psychology)-Social aspects-Case studies. 6. Hospitals-Staff-Case studies. I. Leonard, Pauline, 1957- II. Title.

HD6060.6.H353 2006

$306.3^{\prime} 615-\mathrm{dc} 22$

2005058982

$\begin{array}{llllllllll}10 & 9 & 8 & 7 & 6 & 5 & 4 & 3 & 2 & 1\end{array}$

$\begin{array}{llllllllll}15 & 14 & 13 & 12 & 11 & 10 & 09 & 08 & 07 & 06\end{array}$

Transferred to Digital Printing 2011. 
To Jon Clark: a friend and inspiration, To John Holden: a father who always believed I could. 


\section{Contents}

$\begin{array}{lll}\text { Preface viii } & \text { vii }\end{array}$

Acknowledgements xii

Chapter 1 Introduction 1

$\begin{array}{lll}\text { Chapter } 2 & \text { Situating Identities } & 18\end{array}$

Chapter 3 Researching Identities 35

Chapter 4 Placing Identities 48

Chapter 5 Spaces of Identity 76

Chapter 6 Everyday Times 100

$\begin{array}{lll}\text { Chapter } 7 & \text { Lifetimes } & 127\end{array}$

Chapter 8 Negotiating Identities in Gendered Organizations 157

References 179

Author Index $\quad 188$

Subject Index 191 


\section{Preface}

Issues of identity and change are at present of deep concern to many of us, both at work and in our non-working lives. Questions as to who we are, or who we might be, enter our daily lives at many different levels. As individuals, and media consumers, we are constantly encouraged to think about and perhaps work upon our personal identities, as social and cultural processes emphasize constant self-evaluation and change. As citizens, many of us have argued for recognition and acceptance of our different identities in terms of our rights and ability to live our lives in different ways. As workers, many of us have been subjected to dramatic redefinitions of our professional and working identities in recent years, such that what it means to be, for example, a teacher, doctor, bank clerk, shop assistant or engineer has changed in both performance and perception. In academia, of course, there has been sustained and sometimes heated debate in the arts and social sciences on issues of personal identity: what it is, where it comes from, and whether or not, or how, it changes. It would appear that identity, in this period of late modernity in which we all live, is both of real personal and practical interest, as well intellectual and theoretical concern.

This book is about identity at all of these levels of interest, through the prism of gender identities at work. At one level, it tells personal stories about a very particular group of people working in two organizations in the South of England with whom we did some research. They are some 50 doctors and nurses working in hospitals that are both involved in substantial organizational and professional changes. Through a detailed ethnographic exploration of the doctors' and nurses' daily working lives, and the hospitals in which they work, we examine the ways in which the various members of each organization make and perform their personal identities at work, and in the interplay with home. We look at the pressures on them to construct certain types of identities as a result of the ongoing cultural and discursive changes in their organizations and professions. We examine closely the distinctive and multiple ways in which each person responds to these, how they carve themselves out in particular ways in their different and distinctive organizational situations.

In particular this is a book about gendered identities. In the stories of our doctors and nurses, it was clear that gender is (still) ever present: explicitly drawn upon as a resource in the construction of people's iden- 
tities or implicit behind the talk about their organization, profession and domestic arrangements, and the consequent opportunities and constraints they felt in their lives. It clearly mattered whether we were talking to a man or a woman - gender was no mere backdrop to their lives and the ways they saw themselves. It was an intrinsic part of the broad social and organizational landscape, which they had to negotiate on a daily basis. But these landscapes were complex, differentiated and unequal: and as such gender was interwoven with other constraints and opportunities in the making of selves and lives. Our book is, then, about negotiating gendered identities at work in a double sense: as women and men negotiate the gendered pressures on them to be certain types of people, they must also, negotiate individual identities for themselves.

Tracing the dynamics of identity from this perspective requires close attention to the intricacies of these every day working lives. But, the detail of these stories and biographies is not only interesting from the micro-processual insight it gives us into gender and identitymaking, and the personal lessons that we may learn from looking at the lives of others. We also develop theoretical understanding of identity at a more abstract level. The stories we tell indicate the complexities of the processes of identity-making at work, the subtlety of the interplay of identity-resources which are drawn upon in this process, the diversity between people, as well as of the intricacy of the power relationships between organization and employee.

The book is about personal identity in another sense too. As its researchers and writers, our identities have, of course, been very much involved in the process at every stage. The research originated, quite a few years ago, from personal and academic concerns with the fact that 'identity' was a highly contested concept in theoretical terms, but very little empirical research existed to explore these rather abstract understandings. We wanted to start to redress this imbalance by designing a research project that focussed quite directly on processes of identity making and performance.

This book is about the research study, but at the same time of course, it is also more than this. It is about our identities as researchers doing the research. We want at all times to acknowledge our own presence in both the ethnographic study we undertook in the hospitals and in the ideas we discuss in this book. As a result, we have not kept ourselves out of the text, or attempted to write in an impersonal or 'objective' style. Throughout the book, we make use of our observations and feelings, and each chapter contains 'vignettes' which acknowledge and record the ways in which we were embedded in the practical process of doing 
research, and the differing experiences we each had. At many times, our professional work identities were questioned too, by either the doctors or nurses we were talking to, or by us as we negotiated ourselves through the research. Sometimes we found the research - and our role as academics - quite difficult to justify: here was someone breaking off from heart surgery to talk to us, there was someone asking us to move out of the way so that they could manoeuvre the crash-paddle machine around us. Whilst at times we felt belittled by what we were doing, at other times we found ourselves treated as important 'management consultants' who were going to sort out the pressures on the nursing staff something that also made us feel as if we had been got 'slightly wrong'! Further, as two women researchers, we were also often reminded of our gender as an aspect of the research process, and the subsequent negotiation of our identities and interpersonal relations that this involved. Some of the male consultants and senior registrars treated us in a similar way to the female nurses they worked with - at times we too felt slightly patronized and sexualized. Female nurses and sisters regularly responded to us as confidantes, sharing mutual experiences and understandings about such aspects as combining childcare responsibilities, pregnancy and birth, or some of the difficulties of working with 'bitchy bosses'. This only served to reinforce our awareness of the ever-present aspect of gender in hospital and organizational life. In spite of these juxtapositions of our identities, we each became totally involved in what was starting to feel like a new set of workplaces. The quite different spatial and temporal experiences that the research sites offered added to these new performances of ourselves. Whilst the windswept South coast was battering Susan, Pauline might be negotiating through the manicured landscapes of business park-land. The architecture of each hospital started to feel welcoming and familiar. We came to enjoy meeting in 'Daphne's', the sixties-style café in one of our hospitals for coffee and a chat with the head cook. Night shifts too were an eyeopener: at 3a.m. in the morning, one of us was having tea, biscuits and a cosy gossip with the night staff of a geriatric ward, the other was sharing sausage sandwiches and a joke-swapping session with the doctors in A and E. Our working lives at Southampton often felt a long way away.

Getting to know the places, spaces and times of our doctors' and snurses' lives was crucial to understanding their worlds of work and how they were in them. We needed not only to talk to them about their work but to see them in it - being doctors and nurses. What were they like at $2 o^{\prime}$ clock in the morning and was that any different from 2 o'clock in the afternoon? The participants in our research were all doc- 
tors and nurses: but how much did it matter whether they were in one town or another? One hospital or another? One ward or another? Or on a night shift or a day shift?

This book will reveal that it did and does matter, and that a knowledge of place, space and time enables a distinctive approach to analysing and understanding processes of identity-making in work organizations. This is at once about both the personal and the particular, for it is through a focus on the mundane, everyday routines of lives, set as they are in the particular landscapes of work organizations, that broader theoretical questions of identity may be addressed. 


\section{Acknowledgements}

Creating this book has been a challenging process: exciting, exhilarating and exasperating. Not to mention taking a long time. Ultimately we are responsible for its flaws and imperfections, and we are only too aware of these. But we are indebted to many people and organizations, in many different ways for their support. Without ESRC funding, the research which underpins this book could not have begun. We are grateful too for ESRC support through maternity leave for both of us, despite the incredulity of some in academia that such a thing should be allowed! But without the help and enthusiasm of the managers, doctors and nurses in each of our two hospitals nothing could have happened next. We were amazed, invigorated and touched by the interest that was shown in our research - at least by enough people at each hospital - and by the resources that they made available to us. We are grateful too to the British Medical Association for their interest in our research, and for the fascinating, if truncated, study of race and racism in medicine that began from our shared interests. The encouragement of the Royal College of Nursing Institute at Oxford was heartwarming. Earlier versions of the work in this book have been presented at meetings of the International Sociology Association, The Institute of British Geographers, The Association of American Geographers, the British Sociological Association, and at the Gender, Work and Organization conferences and we are grateful to members of these audiences for their feedback and suggestions, many of which have made their way into this book in one form or another. We would also like to thank our colleagues at Southampton for providing an interesting, lively and dynamic context for our research.

Finally, Susan would like thank Dave Laflin, for his unwavering belief, Alice and Esme for their healthy perspective on life and colleagues at NORUT Social Science in Tromsø, Norway, especially Ann Therese Lotherington, for providing a welcoming home in the last stages of writing this book. Pauline would like to thank Guy for his real interest and continuous support, and William, Frances, Edward and Emily for their patience when 'mum is in her study' - and their ability to get her out of it. Badger and Molly have also provided amazing stress counseling. 